\title{
Identificação Molecular de Bactérias Lácticas com Potencial Probiótico Presentes em Queijo Minas Padrão Artesanal
}

Tuânia Natacha Lopes Silva*, Mariana Andrades Mendes Chaves, Paulo Afonso Granjeiro, Helder Magno Valadares, Débora de Oliveira Lopes , Juliana Teixeira de Magalhães

Universidade Federal de São João Del-Rei, Divinópolis/MG

*e-mail:tuanianlsilva@hotmail.com

\section{Resumo}

Probióticos são micro-organismos vivos contidos em suplementos alimentares, capazes de produzirem efeitos benéficos no hospedeiro, favorecendo o equilíbrio e o incremento da microbiota nativa. Para maior segurança de um produto probiotico é de insuma importância a correta e segura identificação dos isolados, o que nem sempre é possível por testes bioquímicos ou fenotípicos, sendo necessário, então, a identificação molecular. Assim, o presente trabalho tem como intuito a identificação molecular de dez bactérias láticas com potencial probiótico isoladas de Queijo Minas Padrão artesanal adquiridos no município de Divinópolis- MG. Os isolados foram submetidos a metodologia de PCR usando primers específicos a região do gene rDNA 16S: 27F (5' AGATTTGATCCTGGCTCAG 3') e 1492R (5' GGTTACCTTGTTACGACTT $\left.3^{\prime}\right)$. A PCR foi realizada por 3 minutos a $94^{\circ} \mathrm{C}$; seguido por 30 ciclos de 1 minuto à $94^{\circ} \mathrm{C}, 1$ minuto a $55^{\circ} \mathrm{C}$ e 2 minutos a $72^{\circ} \mathrm{C}$ e, posteriormente 8 minutos a $72^{\circ} \mathrm{C}$. Para as reações foram utilizados 50ng de DNA, $1 \mathrm{mM}$ de $\mathrm{dNTP}, 0,36 \mu \mathrm{M}$ de cada primer, 2,5 U de Taq DNA polimerase,tampão da enzima $1 \mathrm{X}$ e $50 \mathrm{mM}$ de $\mathrm{MgCl}_{2}$. $\mathrm{O}$ material foi submetido ao sequenciamento e as sequências comparadas em bancos de dados. A análise possibilitou a identificação de quatro bactérias lácticas: Leuconostoc mesenteroides, Weissella paramesenteroides, Lactobacillus plantarum e Lactobacillus paraplantarum. A partir desta identificação,estudos para confirmar o potencial probiótico das linhagens serão conduzidos, para futuramente ser possível utilizá-las em alimentos probióticos.

Palavras-chave: bactérias lácticas, identificação molecular , probiótico. Agradecimentos: CNPq, FAPEMIG, UFSJ 